\title{
Purchase Intention on Halal Food Products: Non-Muslim Consumers' Perception
}

\section{Norfarah Nordin \& Hana Alesha Teoh Sing Yee}

To Link this Article: http://dx.doi.org/10.6007/IJARBSS/v11-i11/11632

DOI:10.6007/IJARBSS/v11-i11/11632

Received: 16 September 2021, Revised: 20 October 2021, Accepted: 04 November 2021

Published Online: 23 November 2021

In-Text Citation: (Nordin \& Yee, 2021)

To Cite this Article: Nordin, N., \& Yee, H. A. T. S. (2021). Purchase Intention on Halal Food Products: NonMuslim Consumers' Perception. International Journal of Academic Research in Business and Social Sciences, 11(11), 2204-2222.

\section{Copyright: @ 2021 The Author(s)}

Published by Human Resource Management Academic Research Society (www.hrmars.com)

This article is published under the Creative Commons Attribution (CC BY 4.0) license. Anyone may reproduce, distribute, translate and create derivative works of this article (for both commercial and non0-commercial purposes), subject to full attribution to the original publication and authors. The full terms of this license may be seen at: http://creativecommons.org/licences/by/4.0/legalcode

Vol. 11, No. 11, 2021, Pg. $2204-2222$

Full Terms \& Conditions of access and use can be found at http://hrmars.com/index.php/pages/detail/publication-ethics 


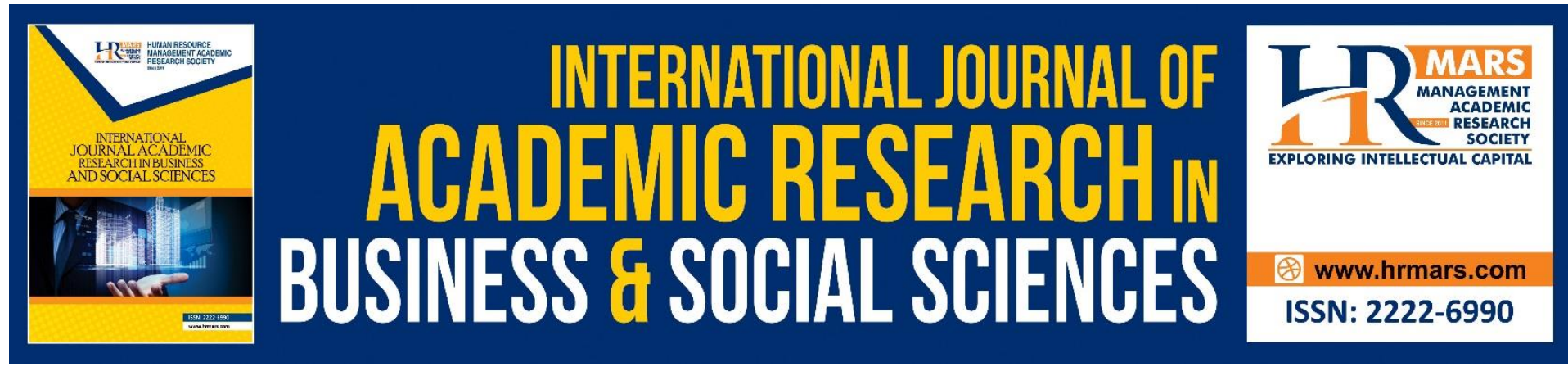

\title{
Purchase Intention on Halal Food Products: Non- Muslim Consumers' Perception
}

\author{
Norfarah Nordin \& Hana Alesha Teoh Sing Yee \\ Graduate School of Business, Universiti Sains Malaysia, Penang, Malaysia \\ Corresponding Email: norfarah@usm.my
}

\begin{abstract}
This research examined the perceived behavioural control, attitude and subjective norms with the presence of moderator variables i.e., religiosity and social media that influence the non-Muslim consumers' buying intention towards halal food products. The questionnaires were distributed to 310 non-Muslim consumers in Penang, Malaysia. Data was analysed using Partial Least Square approach. The research found that perceived behavioural control, attitude and subjective norms are positively related to buying intention of halal food products. Furthermore, religiosity is found to be significant in moderating the relationship between subjective norms towards halal food product buying intention. But religiosity is not a significant moderator in the relationship between attitude and perceived behavioural control towards purchase intention. Similarly, social media only moderates the relationship between subjective norms towards halal food product buying intention. The result of the findings is beneficial for researchers in understanding the buying intention of halal food products among the non-Muslim consumers. The outcome of the research could serve as an essential guidance to the halal food industry player.
\end{abstract}

Keywords: Purchase Intention, Halal Food, Planned Behaviour, Social Media

\section{Introduction}

Halal food is intended to fulfil the Islamic dietary condition and is the condition that practiced by the Muslims around the world. The field of halal may include in all the aspects such as pharmaceutical, beauty products, financial tools, toiletries, banking and commerce (Ali \& Khushi, 2017). Moreover, halal practices are not only restricted to a religion matter anymore but is in the worldwide business sphere (Mukhtar \& Butt, 2012). Halal industry especially in food sector is becoming flourishing in Malaysia recently (Mathew et al., 2012).

Demand of consumers on the type of food also changed rapidly. Habibah (2011) discussed that the Malaysia government has aimed to upgrade Malaysia into a halal Hub and this sector has a rising recognition in recent years and also create more business opportunities to new comers or existing halal food producers or manufacturers to expand their business to worldwide or locally. Even though halal concept usually linked with Muslim society, but there is a huge prospect to tap the non-Muslim's consumer when it comes to food and beverages (Syed \& Nazura, 2011). Moreover, food is the basic needs among human and thus the halal 
market potential is even more auspicious though consumers from different religion and culture backgrounds have different variety of perception and experience to food (Mathew et al., 2012). Furthermore, these days, non-Muslim's consumer understand the halal logo on the food can guarantee the cleanliness and safe to be eaten. Hassan et al (2009) mentioned that non-Muslims do react positively towards halal food certification.

It is widely believed that the Muslim consumers support halal food. In addition, a lot of studies have been carried out among Muslims on halal food consumption (Jan \& Wallace, 2017). Nonetheless, there are limited research on halal food product among non-Muslim consumers in Penang rather than focusing on whole Malaysia (Ngah et al., 2014). Information which provides insights and study potential among non-Muslims in Penang is still limited (Penang Monthly, 2019). In Malaysia, 36.3\% are the non-Muslims (Country Meters, 2020). This percentage of non-Muslim customers suggested the possibility of leveraging into this segment as the niche halal segment, which could then contribute more to the expansion of the halal food industry. Muhammad et al (2007) mentioned that halal food products not only beneficial to the Muslims but everyone in general.

However, Syed \& Nazura (2011); Mathew et al (2014) discussed that many of the non-Muslims consumers yet label the halal food products as Islamic food. Hence, as a result, it is crucial to conduct a study on measuring the halal food product buying intention by using Theory of Planned Behaviour (TPB) attributes. Therefore, this research aimed to analyse the relationship between the TPB attributes (i.e., attitude, perceived behavioural control, subjective norms) towards the halal food product buying intention with the presence of the two moderators (social media influence and religiosity).

The result of the study will be beneficial to food product producers. For the halal industry, this study shall be beneficial to halal products producer's especially those engaged in food industry in Penang. The findings from this research will help the organization to understand their potential customer's behaviour such as attitude, subjective norms, perceived behavioural control and the moderating effect of consumers' characteristics such as religiosity and social media influence on the relationship between attitude, subjective norms, perceived behavioural control and purchase intention. Moreover, this study will also contribute to the newcomers of the halal industry who intended to enter the market and those existing organization to improve their products or services. This research can also be referred as part of consumer behaviour towards halal goods and services in worldwide or in other states of our country.

From theoretical point of view, this research contributes to confirm or refute the useability of theory of planned behaviour in the context of halal product purchase intention. Moreover, this research hypotheses that religiosity and social media influence will moderate the effect in the relationship between all three determinants towards purchase intention.

Next section will discuss on the related literature in this area, followed by methodology of study. The subsequent section discussed the data and findings. Finally, the paper ends with conclusion. 


\section{Literature Review}

\section{Theory of Planned Behaviour}

Theory of Planned Behaviour (TPB) was developed and supported by a number of empirical studies on social psychology and consumption related research (Ajzen, 1991). This theory identifies the influence of the determinants and change behavioural (Ajzen, 1985). Liang (2016) highlighted that TPB is a cognitive behavioural model where the human behaviour is solely based on the perceived behavioural control, subjective norms and attitude that shaping the behavioural intention. Researcher also explained that behavioural intention is the ability of a consumer's plan to carry out a behaviour. Blackwell et al (2006); Ajzen (2001) stated that degree of unfavourable or favourable evaluation towards a behaviour is known as attitude. The second factor - subjective norms was recognized as perceived social pressure to comply with expectation (Syed \& Nazura, 2011). The feeling of being confidence or in control in performing a behaviour is known as perceived behavioural control (Syed \& Nazura, 2011). Commonly, a person likely to perform a behaviour if they have high positive attitude which lead to high social expectation and control (Ajzen, 1985).

Within the halal food context, this theory has been applied to investigate the intention of consumers to consume, buy and accept the halal food product (Nazahah \& Sutina, 2012). TPB was also been applied in one of the studies in Pakistan to investigate the relationship of TPB constructs and halal purchase intention of the Muslims while religiosity act as moderator. In addition, it has been mentioned that religion is crucial when a consumer is making decision for food consumption (Ahamd et al., 2013). Alongside, religiosity also affect a consumer's action and behaviour to purchase halal food (Weaver \& Agle, 2002). As to influence a consumer's behaviour, affiliation and commitment with religion is the main facets.

In past studies of Warokka \& Gallato (2012); Pavalou \& Chai (2002); Montalvo (2006); Yu \& Wang (2018); Apdi (2019) propose social media influence and societal references can be review as a moderator to strengthen the relationship of the factors such as attitude, perception, perceived behavioural control, motivation, social norms, switching intention and purchase behaviour. By adopting this dogma, this study hypothesised that social media influence will moderate the purchase intention model.

\section{Research Variables}

\section{Purchase Intention}

Buying intention is defined as consumers is agreed to engage into a transaction with the seller (Rizwan et al., 2014). In generally, buying intention usually referred to possibility of a consumer will buy a chosen product as it might be due to their daily needs, attitude or perception (Lim, 2013). Fishbein \& Ajzen, (1975) mentioned purchase intention has been applied in many studies as a subsequent purchase's predictor and it was proven that it is positively related with actual behaviour.

To further explain the factors that contribute to buying intention, Theory of Planned Behaviour (TPB) is widely used to explain the perception, attitude and behaviour of the consumers. This theory also helps to provide better understanding and predict the human behaviour (Ajzen, 1985). The TPB was developed as the extension of Theory of Reasoned Action (TRA). The contrast between the theories is adding perceived a behavioural control whether to conduct the behaviour or not (Ajzen, 1985). Alam \& Sayuti (2011), discussed that 
TPB, attitude towards the target behaviour, subjective norms which engage in a behaviour and perceived behaviour control over engaging in a behaviour is the determinants influencing the intention and purchasing behaviours. Various research related to psychology and consumption provide empirical support for TPB (Ajzen, 1991). Memon et al (2019) highlighted TPB has been effectively used to study behaviour of consumers. For instance, Bonne et al (2007) conducted research on attitude towards purchasing halal meat and finds that attitude, social norms as well as perceived behaviour control tend to significantly influence the intention for halal meat consumption.

Several studies on purchase intention have been conducted and showed different factors that affect a person buying intention in food related aspects (Aziz \& Chok, 2013), personal care products (Rahman et al., 2015), halal organic food (Ariffin et al., 2019), banking industries (Amin, 2013). There are numbers of perspectives on purchase intention towards halal products.

\section{Attitude}

According to Blackwell et al (2006), 'evaluation of performing a particular behaviour which associate with the attitude object such as buying a service or product' is known as attitude. Attitude also indicates whether a consumer acquire likeable or dislikeable appraisal of a behaviour in question (Alam \& Sayuti, 2011). Ajzen (1991) mentioned the intensity of intention to conduct a behaviour is depend on the intensity of favourability of the attitude. Kaur et al (2014) emphasized that attitude is one of the main reasons for working women to purchase halal cosmetic products. Rahman et al (2015); (Mukthar \& Butt, 2012) discussed that attitude has a significant relationship towards purchasing intention of halal brands. In addition, Lada et al (2009) explained that attitude plays a positive effect during purchasing of halal products. Therefore, the hypotheses are developed as:

H1: Attitude has a positive association towards the non-Muslim purchase intention of halal food product.

\section{Subjective Norms}

Based on Ajzen \& Fishbein (1980), an attitude towards a particular behaviour is named as subjective norms. In other word, a person perception regarding social factors which influence the performance of a behaviour. A person 'normative belief shows that the perceived behavioural expectations from influential referent groups of people such as partner, family members, and friends (Ajzen 2002), and this normative belief or the motivation to fulfil the perceived expectations of the influential referents might be the factor of a perceived subjective norms (Wilson and Grant, 2013). From the previous researcher (Bonne et al., 2007); (Yoh et al., 2003) analysed that friends and family members certainly influence a consumer's product choice.

Furthermore, subjective norms can affect a person's decision to purchase halal food product when that individual undergo some pressure from the influential referents which as might be the pressure group (Wilson and Grant, 2013). According to Suki and Salleh (2016) identified that consumers take their referent group's opinion who support their purchase intention related to 'halal' products. Therefore, if the consumer that believe is their crucial referents, then they performed the behavioural (Ariffin et al., 2019). Past researcher Mukhtar and Butt (2012) discussed that subjective norms are the most significant predictors for choosing halal 
product compare to other determinants in TPB. Thus, this research proposes the following hypotheses:

H2: Subjective norms have a positive effect on non-Muslim's purchase intention towards halal food product.

\section{Perceived Behavioural Control}

Memon et al (2019) mentioned that perceived behavioural control is a predictor to which a person feels that they have the ability to perform certain behaviour. In addition, there are two conditions of PBC which are the ability to control over the behaviour and level of confidence to conduct certain performance by that person (Memon et al., 2019). Ajzen (1991) stated perceived behavioural control can be decided by a person belief over their internal power and situational factors that enable a behaviour performance. Ajzen, (2005) mentioned it is a person capability to perform a specific behaviour. Besides, perceived behavioural control do have indirect and direct effect on a person's behaviour and intention (Noar \& Zimmerman, 2005). A consumer will maintain their level of control of self-confidence to conduct a behavioral intention (Ajzen, 2005). By combining both perceived behavioural control and intentions of a consumer, we are able to predict their behaviour (Ajzen, 1991). Based on Alam and Sayuti (2011), their research showed perceived behavioural control is significant towards purchase intention in halal products. Kim et al (2011) also discussed that there is a positive influence between perceived behavioural control and purchase intention. Omar et al., (2012) perceived behavioural control is significant over buying intention. Thus, this study proposes a hypothesis as stated:

H3: Perceived Behavioural Control is positive association towards purchase intention of halal products.

\section{Religious as a Moderator}

Most of the research focus on investigating the moderating effect of religious on the relationship between the theory of planned behaviour's constructs and halal buying intention. However, in this study, religious is chosen as a moderator due to several reasons. In some studies, it was stated that attitude is one of the important determinants but perceived behavioural control does not contribute any significance to buying intention (Ansari \& Muhammad, 2015). Mukhtar \& Mohsin (2012) stated subjective norms is a crucial factor of intention when consumer decided to buy the halal products. Lee and Green (1991) mentioned subjective norms act as important determinant in buying behaviour in Philippines. Huang et al (2008) showed that subjective norms is not significant at all towards buying intention. Mukhtar \& Mohsin (2012) proved that attitude is significant towards halal product's purchase intention. Alam \& Sayuti (2011) discussed that perceived behavioural control does not contribute any significance towards behavioural intention. Bonne \& Verbeke (2006) found that perceived behavioural control has a significant effect on influencing consumer to buy halal product. Due to the inconsistencies that found in previous researches, (Baron \& Kenny, 1986) emphasized that when determinants or predictor relationship is weak, a moderator must be applied.

Next, reason to select religiosity as a moderator is derived from the studies of Memon et al (2019) who stated that finding the moderation effect on halal purchase intention by using TPB in Pakistan. This study has yet to be apply in the context of non-Muslim consumer's purchase intention of halal food products in Penang. Borzooei \& Asgari (2013), religious as 
moderator in halal behavioural towards purchasing intention is a new field of study. Lindridge (2005) religious as a moderator can help to determine the perception as well as the intention of a consumer.

Thirdly, the past halal purchase intention studies have recommended religiosity might be a potential moderator between perceived behavioural control, subjective norms and attitude (Delener, 1964). (Pettinger et al., 2004) showed that religiosity should be investigate as a moderator in the future study as researcher stated that halal products was linked to religion such as Islam. Lada et al., (2009) analysed that religiosity might contribute good effect on the determinants like subjective norms and attitude in halal product's purchasing intention. Therefore, the following hypotheses is generated:

H4a: The positive association between attitude and non-Muslim consumer's purchase intention of halal food product will be stronger with the presence of religiosity.

$H 4 b$ : The positive relationship between subjective norms and non-Muslim consumer's purchase intention of halal food product will be stronger with the presence of religiosity. H4c: The positive association between perceived behavioural control and non-Muslim consumer's purchase intention of halal food product will be stronger with the presence of religiosity.

Social Media Influence as Moderator

Apdi (2019) defined the social media as internet-based applications which allows exchanging and creating user generated content. Author also mentioned that web page such as YouTube or Facebook are the web site that allows content sharing and creation. Boyd \& Ellison, (2007); Kaplan \& Haenlein (2010) defined social media as an internet service that creates an online environment that enable a person to communicate with other users and in the same time exchange information. With this market environment, it has changed the communication among the business organization, government and individual (Haro-de-Rosario et al., 2018). Social media also encourage consumers to build and maintain social relationship, and exchange information (Trusov et al., 2009). This kind of information could be in the form of video and comments, or pictures, consumer's past experience or review of products, service or brand, and public discussion about an issues or news (Tuten \& Solomon, 2017). Alboqami et al (2015) discussed that these huge platforms with interestingly consumer draw the attention of the organization to contact the existing and potential consumers through such platforms. Twitter of companies use these websites to engage with consumers and promote their products and services. Through this kind of platform, organizations or individual seller rapidly manage their interactions with the wider consumer community and other business organization (B2B) (Glenn, 2011).

While most of the organization dealing with halal products or other ways of engaging the Muslim and non-Muslim's market had created the online presence through their company web page or apps. Apdi (2019) discussed evidence shows that relatively few sellers or organizations appear actively to utilize online interactivity facilitated by social media, and potential all these has boost the relationship they have with the customers. Social interaction can be facilitated by social media which exert a strong influence on opinion formation (Buchanan, 2007). In China, social media has even greater influence on buying decision as the China locals more likely to consider purchase a product if they witness it discussed positively by friends on social media like WeChat (Chiu et al, 2012). Yu \& Wang, (2018); Ayuniyyah \& 
Hambar (2017) mentioned the information acquisition via social media increase the digital peer pressure which led to purchase intention in the end.

In past studies of Warokka \& Gallato (2012); Pavalou \& Chai (2002); Montalvo (2006); Yu \& Wang (2018); Apdi (2019) these researchers surveyed their current along with some various past studies propose social media influence and societal references can be review as a moderator to strengthen the relationship of the factors such as attitude, perception, perceived behavioural control, motivation, social norms, switching intention and purchase behaviour. Therefore, the following hypotheses is generated:

H5a: The positive association between attitude and non-Muslim consumer's purchase intention of halal food product will be stronger with the presence of social media influence.

H5b: The positive association between subjective norms and non-Muslim consumer's purchase intention of halal food product will be stronger with the presence of social media influence.

H5c: The positive association between perceived behavioural control and non-Muslim consumer's purchase intention of halal food product will be stronger with the presence of social media influence.

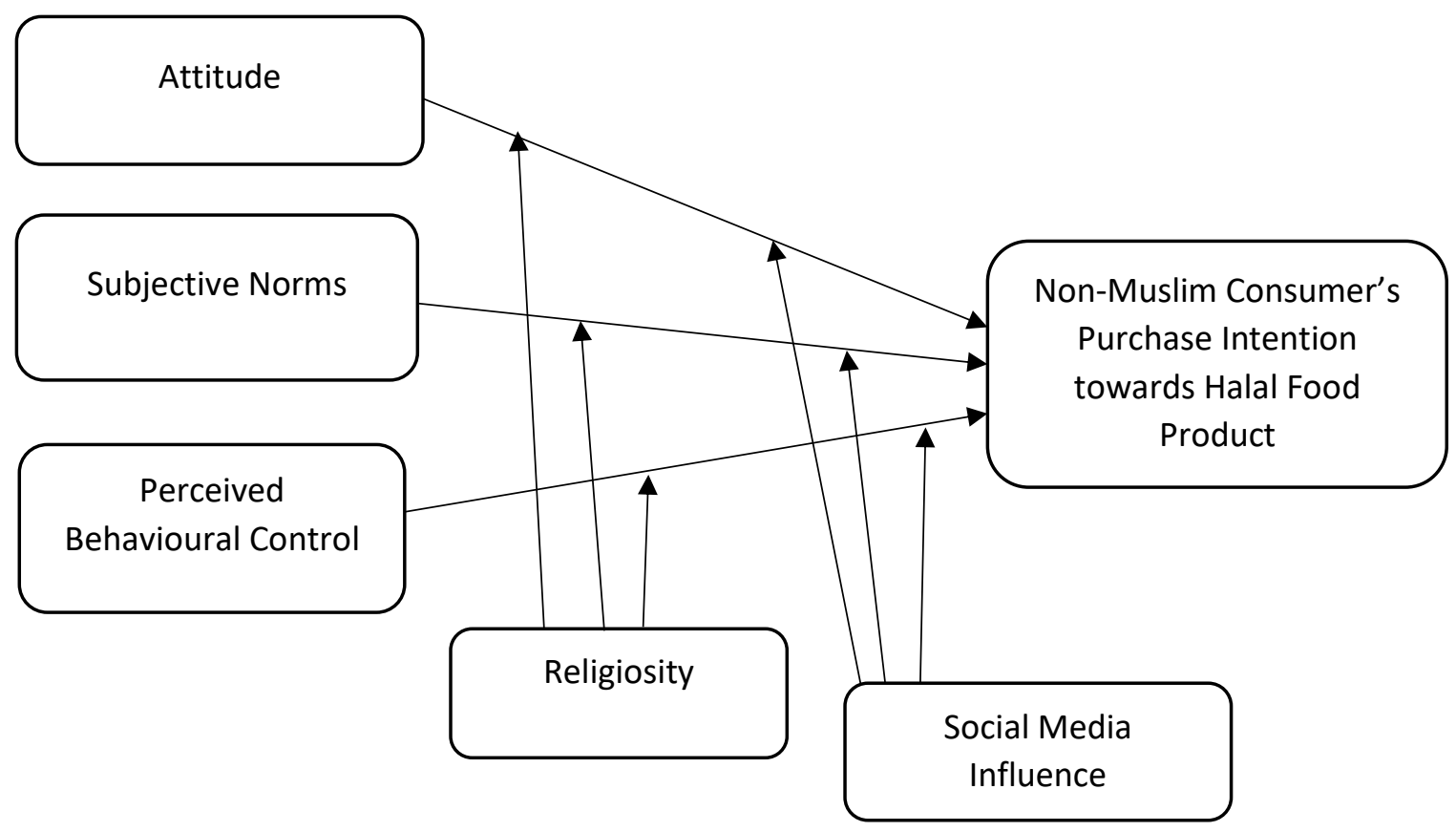

Figure 1: Conceptual Framework of study

\section{Methodology}

\section{Data Collection Method and Instrument}

This research was carried out in Penang and only the non-Muslim were targeted as to gather the information of halal food product's purchase intention. This is due to the researcher is based in Penang and it is easier and more convenient to obtain the data from the non-Muslim. Data was gathered through online Google Survey and the survey link will provide to the right targeted group of participants only. Kline (2014) highlighted a data collection should not be less than 100 respondents. An ideal sample size adequacy was proposed by Comrey and Lee (1992) that 1000 or more (excellent), 500 (very good), 300 (good), 200 (fair), 100 (poor) and 
50 (very poor). Non-Muslim's consumer who stays in Penang who have the intentions to buy halal food products are targeted for data collection and sample size for this research is 300 as proposed by (Kline, 2014).

In order to obtain the data, 5 points Likert Scale was adopted ( 5 strongly agree; 1 strongly disagree) questionnaire which was adopted and adapted from previous studies such as Haque et al. (2015); Wilde \& Joseph (1997); and Ayyuniyah \& Hambari (2017) with total of 26 items. In quantitative research, data is collected through survey, secondary sources or questionnaire. However, questionnaire is the most ideal and widely practiced approach (Ticehurst \& Veal (2000).

\section{Sampling Technique}

In this study, purposive sampling was applied. A non-probability sampling which decided on objective of the research as well attributes of the population is known as purposive sampling (Ali \& Khushi, 2017). This sampling technique was used when researcher targeted specific group of participants from the whole population (Black, 2010). A self-administrated online questionnaire was distributed to a total of 310 respondents. Respondent from this research were qualified according to researcher's screening criteria which, they are non-Muslims and lived in Penang.

\section{Data Analysis and Findings}

This study analysed the survey data using SmartPLS software to test the direct and moderation effect hypothesised in the model. The descriptive data are analysed SPSS software. Table 1 showed that the sample comprises of 139 (44.8\%) men and 171 (55.2\%) women. From the respondent's age characteristic, it reported a total of $186(60 \%)$ were dominant by 25 to 34 years old group of people. A total of $67.1 \%$ of respondents were mainly single marital status. Most of the respondents had a higher education background such as bachelor degree which made up $47.7 \%$ and $27.4 \%$ were Master's holder. Not only that, most of the respondents have 4 to 5 family members (45.8\%). Moreover, 19.4\% of the respondents indicated that their monthly where around RM2001-RM3000 and 73.9\% of respondents were employed. 
Table 1: Respondents' Demographic Profile

\begin{tabular}{|c|c|c|c|}
\hline Characteristic & Categories & Frequency & Percent \% \\
\hline \multirow[t]{2}{*}{ Gender } & Male & 139 & 44.8 \\
\hline & Female & 171 & 55.2 \\
\hline \multirow[t]{6}{*}{ Age } & $18-24$ years old & 54 & 17.4 \\
\hline & $25-34$ years old & 186 & 60.0 \\
\hline & $35-44$ years old & 30 & 9.7 \\
\hline & $45-54$ years old & 15 & 4.8 \\
\hline & $55-64$ years old & 16 & 5.2 \\
\hline & 65 years old and above & 9 & 2.9 \\
\hline \multirow[t]{3}{*}{ Marital Status } & Single & 208 & 67.1 \\
\hline & Married & 92 & 29.7 \\
\hline & Divorced/ Widowed & 10 & 3.2 \\
\hline \multirow[t]{6}{*}{ Educational Level } & Primary School & 8 & 2.6 \\
\hline & Secondary School & 23 & 7.4 \\
\hline & Diploma & 42 & 13.5 \\
\hline & Bachelor Degree & 148 & 47.7 \\
\hline & Master's Degree & 85 & 27.4 \\
\hline & PHD & 4 & 1.3 \\
\hline \multirow[t]{4}{*}{ Family Size } & 1 person & 7 & 2.3 \\
\hline & 2-3 person & 90 & 29.0 \\
\hline & 4-5 person & 142 & 45.8 \\
\hline & More than 5 persons & 71 & 22.9 \\
\hline \multirow{11}{*}{$\begin{array}{l}\text { Income Level } \\
(\mathrm{RM}) / \text { monthly }\end{array}$} & RM1000 and below & 39 & 12.6 \\
\hline & RM1001-RM 2000 & 17 & 5.5 \\
\hline & RM2001- RM3000 & 10 & 3.2 \\
\hline & RM3001- RM4000 & 31 & 10.0 \\
\hline & RM4001- RM5000 & 60 & 19.4 \\
\hline & RM5001- RM6000 & 53 & 17.1 \\
\hline & RM6001-RM7000 & 31 & 10.0 \\
\hline & RM7001-RM8000 & 36 & 11.6 \\
\hline & RM8001-RM9000 & 11 & 3.5 \\
\hline & RM9001-RM10,000 & 12 & 3.9 \\
\hline & RM10,000 and above & 10 & 3.2 \\
\hline Employment & Employed & 229 & 73.9 \\
\hline \multirow[t]{3}{*}{ Status } & Unemployed & 20 & 6.5 \\
\hline & Pension & 13 & 4.2 \\
\hline & Student & 48 & 15.5 \\
\hline
\end{tabular}

Measurement Model Assessment

Table 2 summarises the results of the measurement model. The results indicated that all the measurement items are valid and reliable. Table 3 summarises the constructs' discriminant validity. 
Table 2: Measurement Model

\begin{tabular}{lccccc}
\hline & Measurement Items & FL & CA & AVE & CR \\
\hline Attitude $(A)$ & & 0.814 & 0.876 & 0.661 & 0.907
\end{tabular}

A1. Choosing halal food products is a good idea.

A2. I feel comfortable to consume halal food $\quad 0.738$ products.

A3. I am satisfied with the halal food products. $\quad 0.794$

A4. Halal food products are safer and more hygienic. $\quad 0.880$

A5. Halal food products are environment friendly $\quad 0.834$

Subjective Norms (SN)

$\begin{array}{llll}0.833 & 0.894 & 0.705 & 0.922\end{array}$

SN 1. The people around says that halal food products have better quality.

SN 2. My family members favour halal food products. $\quad 0.875$

SN 3. My friends recommend to consume halal food $\quad 0.859$ products.

SN 4. Obtaining halal food is part of a natural way of $\quad 0.877$ living.

SN 5. I read good things about halal food products in $\quad 0.746$ the newspapers.

$\begin{array}{lllll}\text { Perceived Behavioural Control (PBC) } & 0.804 & 0.864 & 0.710 & 0.907\end{array}$

PBC 1 . I can easily buy halal food

PBC 2. Halal food are simply available at nearby store $\quad 0.812$

PBC 3. Halal food products are accessible for me. $\quad 0.877$

PBC 4. I believe I can manage halal food products. $\quad 0.874$

$\begin{array}{lllll}\text { Religiosity }(R) & 0.787 & 0.902 & 0.775 & 0.932\end{array}$

R1. I pray a lot.

R2. Being religious helps me to lead a better life. $\quad 0.902$

R3. I believe God helps people. $\quad 0.914$

R4. I believe that God listens to my prayers. 0.911 


\begin{tabular}{lllll}
\hline Social Media Influence (SMI) & 0.858 & 0.912 & 0.790 & 0.938
\end{tabular}

SMI 1. Social media inspires me to buy halal food.

SMI 2. Social media constantly endorse halal logo $\quad 0.886$ food.

SMI 3. Social media makes halal food a trend.

SMI 4. I buy halal food product because of social media promotion.

Purchase Intention (PI)

$\begin{array}{llll}0.827 & 0.834 & 0.667 & 0.888\end{array}$

PI 1. I would consider buying halal food product.

PI 2. I always buy halal food product.

PI 3. I usually pick food with halal label.

0.851

PI 4. I choose halal food when shopping.

0.692

Table 3: HTMT (0.90)

\begin{tabular}{ccccccc}
\hline & $\mathrm{A}$ & $\mathrm{PBC}$ & $\mathrm{PI}$ & $\mathrm{R}$ & $\mathrm{SMI}$ & $\mathrm{SN}$ \\
$\mathrm{A}$ & & & & & \\
$\mathrm{PBC}$ & 0.675 & & & & \\
$\mathrm{PI}$ & 0.720 & 0.890 & & & \\
$\mathrm{R}$ & 0.170 & 0.381 & 0.385 & & \\
SMI & 0.404 & 0.703 & 0.640 & 0.253 & \\
SN & 0.717 & 0.891 & 0.845 & 0.397 & 0.707 \\
\hline
\end{tabular}

\section{Structural Model Assessments}

In this section, Table 4 indicated the result of $R^{2}$ value was 0.773 which explained that $77.3 \%$ of the variance in the buying intention of the respondents towards halal food products can be illuminated by perceived behavioural control, attitude and subjective norms. Besides the analysis of $R^{2}$, predictive metric assessment such as $Q^{2}$ is crucial as one of the conditions of predictive relevance ((Stone, 1974; Geisser, 1974). $Q^{2}$ can be done through Blindfolding process in PLS-SEM. Hair et al., (2018) mentioned that $Q^{2}$ value which is $0.50,0.25,0$ illustrated as large, medium, small predictive accuracy of the PLS path model. In this study, $\mathrm{Q}^{2}$ was 0.492 . Hence, the model portrayed a high predictive relevance. 
Table 4. Coefficient of Correlation

\begin{tabular}{ccc}
\hline & R square & R square adjusted \\
\hline Purchase Intention & 0.773 & 0.765 \\
\hline
\end{tabular}

\section{Hypothesis Analysis}

In this assessment of inner models, it helps to examine the relationship between independent variables (IV) and dependent variable (DV). Structural Model is applied to test the hypotheses. According to this study, several numbers of path coefficient were analysed by using PLS-SEM algorithm and the significant of the relationship will be examined by bootstrapping process. The data for bootstrapping were 5000 samples (Hair et al, 2017) as to obtain the structural model. This is to show the path coefficient of the DV and IVs. The outcome indicates the result of the relationship between the IVs and DV are significant at p-value less than 0.05 (Hair et al, 2018); t-value above 2.3265 considered accepted (Hair et al, 2017). Table 5 indicates the result of the analysis. The attitude $(\beta: 0.167$; t-value: $4.072 ; p<0.01)$ has a positive effect towards the non-Muslim's consumers halal food products purchase intention. Thus, H1 is accepted. This finding is similar with Alam \& Sayuti (2011); Rahman et al (2015); Mukthar \& Butt (2012); Lada et al (2009); Ariffin et al (2019) where attitude has a significant and positive relationship towards halal product purchase intention. As Engel et al (1995) claimed, good predictor such as strong attitude will affect a consumer to purchase a product.

Subjective norms also have a positive impact on the halal food product purchase intention for a ( $\beta$ : $0.165 ; t$-value: $2.511 ; p<0.01)$. Hence, $\mathrm{H} 2$ is accepted. This finding shares the same result as the previous studies (Mukhtar and Butt, 2012; Alam \& Sayuti, 2011) which showed a positive and significant influence towards the halal food products purchase intention. This indicates that, halal food product buying intention can be prompted by subjective norms when a consumer face pressure from the referent groups of people, and the consumer might act as what they wish (Wilson \& Grant, 2013).

Perceived Behavioural Control (PBC) with ( $\beta$ : 0.485; t-value: $7.063 ; p<0.05$ ) has a positive and highest $t$-value on halal food buying intention. Thus, $\mathrm{H} 3$ is accepted. The findings are consistent with the past studies (Alam and Sayuti, 2011; Kim et al., 2011; Omar et al., 2012) where PBC are positively and significant towards purchase intention. Kim et al (2011) mentioned the more the person has the degree of control over their decision making in buying halal food product, the more likely they will perform the specific behaviour.

Moreover, religiosity shows positive effect with $(\beta: 0.110$; t-value: $2.861 ; p<0.01)$ towards halal food product buying intention. This outcome is similar with the previous studies (Memon et al., 2019) which showed positive relationship between religiosity and halal food products purchase intention. On the other hand, social media influence shows a positive effect with $(\beta: 0.118$; $t$-value: $2.511 ; p<0.05)$. This result is similar with the past study (Yu \& Wang, 2018) which indicated positive relationship between Social Media Influence and halal food product buying intention. 
Table 5. Hypotheses Results

\begin{tabular}{cccccc}
\hline Relationships & $\begin{array}{c}\text { Path } \\
\text { coefficient }\end{array}$ & SD & T-values & P-value & Decision \\
\hline H1 & 0.167 & 0.041 & 4.072 & 0.000 & Supported \\
H2 & 0.165 & 0.066 & 2.511 & 0.000 & Supported \\
H3 & 0.485 & 0.069 & 7.063 & 0.012 & Supported \\
H4 & 0.110 & 0.041 & 2.861 & 0.004 & Supported \\
H5 & 0.118 & 0.038 & 2.511 & 0.012 & Supported \\
\hline
\end{tabular}

Moderating Effect of Religiosity ( $\mathrm{H} 4 \mathrm{a}, \mathrm{H} 4 \mathrm{~b}, \mathrm{H} 4 \mathrm{C}$ )

Table 6 showed the moderating effect of religiosity and social media influence towards the relationship between determinants and halal food product purchase intention. Based on the interaction effect of religiosity and subjective norms $(\beta: 0.237 ; t$-value: $3.403 ; p<0.01)$ is significant towards halal food product buying intention and thus, $\mathrm{H} 4 \mathrm{~b}$ is accepted. This finding is similar with (Memon et al., 2019; Lada et al., 2009) which indicates a positive outcome in their research. Meanwhile, on the interaction effect between attitude and religiosity on halal food product purchase intention ( $\beta$ : $0.031 ; t$-value: $0.668 ; p<0.01$ ) is found to be insignificant. Thus, $\mathrm{H} 4 \mathrm{a}$ is rejected. This is because the $\mathrm{p}$-value is more than 0.05 as suggested by Hair et al., (2018). This finding is not consistent with the past studies where (Ansari \& Muhammad, 2015; Mukhtar \& Mohsin, 2012) mentioned that attitude is significant towards halal food product buying intention. However, the interaction effect of religiosity and perceived behavioural control (PBC) ( $\beta$ : -0.245 ; t-value: $3.349 ; p<0.01)$ is also found to be in negative relationship towards the buying intention of halal food product. Therefore, $\mathrm{H} 4 \mathrm{c}$ is rejected. The findings is consistent with the past studies where past researcher found out that PBC is negative related to religiosity. (Memon et al., 2019). Therefore, the empirical finding only support H4b.

Moderating Effect of Social Media Influence ( $\mathrm{H} 5 \mathrm{a}, \mathrm{H} 5 \mathrm{~b}, \mathrm{H} 5 \mathrm{c}$ )

Accordingly, the interaction effect of subjective norms and social media influence (SMI) ( $\beta$ : 0.264 ; $t$-value: $4.859, p<0.01$ ) is found to be significant and has a positive relationship towards the halal food product purchase intention. Thus, $\mathrm{H} 5 \mathrm{~b}$ is accepted. This finding is consistent with the previous research Yu \& Wang, (2018) which indicated a positive outcome. However, the interaction effect of attitude and social media influence $(\beta:-0.200 ; t$-value: $6.036 ; p<0.01)$ is found to have a negative relationship. Thus, $\mathrm{H} 5 \mathrm{a}$ is rejected. Moreover, the interaction effect of PBC and SMI ( $\beta$ : -0.170 ; t-value: $2.972 ; p<0.005)$ is found to have a negative relationship as well. Thus, $\mathrm{H} 5 \mathrm{c}$ is rejected. Therefore, the empirical findings only support $\mathrm{H} 5 \mathrm{~b}$.

Table 6. Moderating Effect

\begin{tabular}{cccccc}
\hline Hypothesis & Path coefficient & SD & T-values & P-value & Decision \\
& & & & & \\
\hline H4a & 0.031 & 0.047 & 0.668 & 0.504 & Not supported \\
H4b & 0.237 & 0.070 & 3.403 & 0.001 & Supported \\
H4c & -0.245 & 0.073 & 3.349 & 0.001 & Not Supported \\
H5a & -0.200 & 0.033 & 6.036 & 0.000 & Not Supported \\
H5b & 0.264 & 0.054 & 4.859 & 0.000 & Supported \\
H5c & -0.170 & 0.057 & 2.972 & 0.003 & Not Supported \\
\hline
\end{tabular}




\section{Discussion and Conclusion}

The finding of this research reveals that most of the hypotheses are supported. It displayed that all the supported hypotheses mentioned have positive relationship and significant towards the non-Muslim consumers' halal food buying intention. The finding is consistent with the results of past researches (Alam \& Sayuti, 2011, Rahman et al., 2015; Mukthar \& Butt, 2012, Lada et al., 2009, Ariffin et al., 2019) where attitude has a significant and positive relationship towards halal product purchase intention. As Engel et al (1995) claimed, good predictor such as strong attitude will affect a consumer to purchase a product. This study also finds that halal food product buying intention can be prompted by subjective norms when a consumer received endorsement from their referent groups (Wilson \& Grant, 2013). NonMuslim consumers has control over their decision making, and buying halal food product is likely to occur. Religiosity has a moderation effect on the association between subjective norms and attitude towards halal product's purchasing intention. Information acquisition via social media about halal food leads to positive recommendation which lead to strengthen purchase intention of halal food.

The findings of this research suggested that subjective norms, attitude and perceived behaviour control are the main contributor for buying intention of halal food products with the presence of two moderators such as religiosity and social media influence. This research also illustrate halal behaviours may contribute the promising business opportunity in fast food chain, halal food retailers, manufacturer as well as global halal market. There is a potential for SMEs in halal food product penetrate the non-Muslim consumers. This research has made a practical contribution to the Food \& Beverages (F\&B) SMEs as well as provide better understanding for future researcher in halal F\&B sector.

\section{References}

Aziz, Y. A., \& Vui, C. N. (2012). The role of halal awareness and halal certification in influencing non-Muslims' purchase intention. In 3rd International Conference on Business and Economic Research, Indonesia.

Ahmad, M., Kadir, S. A., and Salehuddin, N. A. (2013). Perception and Behavior's of Muslims and Non-Muslim Towards Halal Products. Journal of Social and Development Sciences, 4(6), 249-257.

Aiedah, A. L., Hayatti, S. I., Hairunnisa, M. I. (2015). A Study on The Factors Influencing Young Muslims' Behavioral Intention in Consuming Halal Food in Malaysia. Shariah Journal, 23(1), 53-74.

Ajzen, I. (1985). From Intentions to Actions: A Theory of Planned Behavior. In J. Kuhl, \& J. Beckmann (Eds.). Action control: From Cognition to Behavior, 11-39. Heidelberg, Germany: Springer.

Ajzen, I. (1991). The Theory of Planned Behavior. Organizational Behavior and Human Decision Processes, 50(2), 179-211.

Ajzen, I. (2001). Nature and Operation of Attitudes. Annual Review of Psychology, 52, 27-58

Ajzen, I. (2002). Perceived Behavioural Control, Self-Efficacy, Locus of Control and the Theory of Planned Behaviour. Journal of Applied Social Psychology, 32(4), 665-683.

Ajzen, I. (2005). Attitudes, Personality and Behaviour. Open University Press, $2^{\text {nd }}$ edn, McGrawHill Education.

Ajzen, I., \& Fishbein, M. (1980). Understanding Attitudes and Predicting Social Behaviour. Prentice-Hall, Englewood Cliffs, NJ. 
Alam, S. S., \& Sayuti, N. M. (2011). Applying the Theory of Planned Behavior in Halal Food Purchasing, International Journal of Commerce and Management, 21(1), 8-20.

Alboqami, H., Al-Karaghouli, W., Baeshen, Y., Erkan, I., Evans, C., \& Ghoneim, A. (2015). Electronic Word of Mouth in social media: The Common Characteristics of Retweeted and Favourited Marketer-Generated Content Posted on Twitter. International Journal of Internet Marketing and Advertising, 9(4), 338-358.

Ali, A., \& Khushi, A. (2017). Purchase Intention for Halal Products in Pakistan; Evidences from Non-Muslim Community. International Journal or Research in Social Science and Humanities, 3(12), 65-86.

Amin, H., Baba, R., and Muhammad, M. Z. (2007). An Analysis of Mobile Banking Acceptance by Malaysia Consumers. Sunway Academic Journal, 4, 1-12.

Ansari, N. U., \& Mohammed, H. (2015). Factors affecting the intent to purchase halal personal care products: empirical evidence from Pakistan. International Journal of Islamic Marketing and Branding, 1(2), 199-213.

Apdi, A. F. (2019). Social Media Consumer Behaviour and Marketing Strategy Implication of Halal about Islamic Marketing Operations. Munich Personal RePEc Archieve (MRPA).

Ariffin, S. K., Dihanan, N. N., \& Abdul Wahid, N. (2019). Investigating the Factors Affecting Consumer Purchase Intention towards Halal Organic Food. Journal of Entrepreneurship, Business and Economics, 7(2), 162-188.

Ariffin, S. K., Azra, F. W., Abdul Wahid, N., \& Nee, Y. G. (2019). Investigating the Factors Affecting Purchase Intention of Muslim Women Towards Halal Cosmetics. Journal of Entrepreneurship, Business and Economics, 7(2s), 78-105.

Ayunniyyah, Q., Hambari, D. H. (2017). Factors Affecting Consumer's Decision in Purchasing MUI Halal-Certified Food Products. Tazkia Islamic Finance and Business Review, 10(2).

Baron, R. M., \& Kenny, D. A. (1986). The Moderator-Mediator Variable Distinction in Social Psychological Research: Conceptual, Strategic, and Statistical Considerations. Journal of Personality and Social Psychological, 51(6), 1173.

Black, K. (2010). Business Statistics: Contemporary Decision Making. $6^{\text {th }}$ edn, John Wiley \& Sons.

Blackwell, R. D., Miniard, P. W., Engel, F. J. (2006). Consumer Behaviour. Mason: Thomson.

Bonne K., \& Verbeke, W. (2006). Muslim Consumer's Motivation Towards Meat Consumption in Belgium; Qualitative Exploratory Insights from Means-end Chain Analysis. Anthropology of Food, 5, 2-24.

Bonne K., Vermeir, I., Bergeaud, B. F., Verbeke, W. (2007). Determinants of Halal Meat Consumption in France. British Food Journal, 109(5), 367-386.

Borzooei, M., \& Asgari, M. (2013). The Halal Brand Personality and its Effect on Purchase Intention. Interdisciplinary Journal of Contemporary Research in Business, 5(3), 251-277.

Boyd, D. M., \& Ellison, N. B. (2007) Social network sites: Definition, history, and scholarship. Journal of computer-mediated communication, 13(1), 210-230.

Bredahl, L., Grunert, K. G., \& Frewer, L. J. (1998). Consumer Attitudes and Decision Making with regards to Genetically Engineered Food Products - A Review of the Literature and a Presentation of Models for Future Research. Journal of Consumer Policy, 21, 251-277.

Bunchanan, A. H., \& Hussin, A. R. C. (2016), Understanding Social Commerce: A Systematic Literature Review and Directions for Further Research, International Journal of Information Management, 36, 1075-1088. 
Chiu, C., Lin, D., \& Silverman, A. (2012). China's Social Media Boom. McKinsey \& Company. Retrieved from https://www.mckinsey.com/business-functions/marketingandsales/our-insights/chinas-social-media-boom (accessed on 1.4.2021)

Collins English Dictionary. (2019). Non-Muslim Definition and Meaning. Retrieved from https://www.collinsdictionary.com/dictionary/english/non-muslim

Comey, A. L., \& Lee, H. B. (1992). Interpretation and Application of Factor Analytic Results. Comey AL, Lee, HB. A First Course in Factor Analysis, 2.

Delener, N. (1994). Religious Constructs in Consumer Decision Behaviour Patterns; Their Dimension and Marketing Implications. European Journal of Marketing, 28(5), 36-53.

Duane, S. E. (2003). Customer Relationship Management Systems Handbook. Washington: Auerbach Publications, 2.

Eagly, A. H., \& Chaiken, S. (1993). The Psychology of Attitudes. Harcourt Brace Jovanovich College Publishers.

Farhangi, A. A., Abbas, A., Farahani, S. B., \& Ghasemi, R. A. (2014). Analyzing the Impact of social media on Consumer Attitudes towards the Brand and their Intention to Purchase. Global Media Journal, Persian edn, 9(2), 68-73.

Fishbein, M., \& Ajzen, I. (1975). Belief, Attitude, Intention and Behavior: An Introduction to Theory and Research. Reading. MA: Addison-Wesley

Geisser, S. (1975). The Predictive Sample Reuse Method with Application. Journal of the American Statistical Association, 320-328.

Glenn, B. (2011). Social Media Phenomenon. Direct Selling News, 7(9), 11-18.

Gong, W. (2009). National Culture and Global Diffusion of Business-to-Consumer ECommerce. Cross Cultural Management: An International Journal, 16, 83-101.

Habibah, C. H. (2011). The confidence level of purchasing product with Halal Logo Among Consumers. Dissertation for Masters. Universiti Utara Malaysia.

Hair, J. F., Ringle, C. M., Gudergan, S. P., Nitzl, A. F. C., \& Menictas, C. (2018). Partial least Square Structural Equation Modeling- Based Discrete Choice Modeling: An Illustration in Modeling Retailer Choice. Bus Res 12, 115-142.

Hair, J. F. G., Hult, T. M., Ringle, C. M., \& Sarsted, M. (2017). In A Primer on Partial Least Square Structural Equation Modeling (PLS-SEM). California: SAGE Publication Inc.

Hamid, M. R. A. B., Sami, W., \& Sidek, M. H. M. (2017). Discriminant Validity Assessment: Use of Fornell \& Larcker Criterion Versus HTMT Criterion. Journal of Physics Conference Series, 890(1),012163.

Haque, A., Sarwar, A., Yasmin, F., Tarofder, A. K., \& Hossain, M. A. (2015). Non-Muslim Consumer's Perception towards Purchasing Halal Food Products in Malaysia. Journal of Islamic Marketing, 6(1), 133-147.

Haro-de-Rosario, A., Sáez-Martín, A., \& Caba-Pérez, D. C. M. (2018) Using social media to enhance citizen engagement with local government: Twitter or Facebook? New Media \& Society, 20(1), 29-49.

Hassan, S. H., Dann, S., Kamal, K. A. M., \& De Run, E. C. (2016). Influence of the Halal certification mark in food product advertisements in Malaysia. In The New Cultures of Food (pp. 265-284). Routledge.

Huang, Q., Davison, R. M., \& Gu, J. (2008). Impact of Personal and Cultural Factors on Knowledge Sharing in China. Asia Pacific Journal of Management, 25(3), 451-471.

Ibrahim, K. (2018). Determinants of Halal: The Relationship Between Social Media News, Information Usefulness, EWOM, Product Judgement and Purchase Intention. University of Hull, United Kingdom. 
Kaplan, A. M., \& Haenlein, M. (2010) Users of the World, unite! The challenges and opportunities of social media. Business horizons, 53 (1), 59-68

Kaur, K., Osman, D. S., \& Maziha, A. P. D. S. (2014). Predicting Working, Women Purchasing Behaviour of Malaysia Halal Cosmetic Products by Using Theory of Planned Behavior. International Academic Research Journal of Business and Management, 3, 1-7.

Kim, M. J., Chung, N., \& Lee, C. K. (2011). The Effect of Perceived Trust on Electronic Commerce Shopping Online for Tourism Products and Services in South Korea. Tourism Management, 32(2), 256-265.

Kline, R. B. (2011). Principles and Practice of Structural Ewuation Modeling. New York: Guilford Press.

Lada, S., Tanakinjal, G. H., \& Amin, H. (2010). Predicting Intention to Choose Halal Products Using Theory of Reasoned Action. International Journal of Islamic and Middle Eastern Finance and Management, 3(4), 66-76.

Lee, C., \& Green, R. T. (1991). Cross-Cultural Examination of the Fishbein Behavioral Intentions Model. Journal of International Business Studies, 22(2), 289-305.

Liang, R. (2016). Predicting Intentions to Purchase Organic Food: The Moderating Effect of Organic Food Prices. British Food Journal, 118(1), 183-199.

Lim, W. M. (2013). Toward a Theory of Online Buyer Behavior Using Structural Equation Modeling. Modern Applied Science, 7, 34-42.

Lindridge, A. (2005). Religiosity and the Constructions of a Cultural-Consumption Identity. Journal of Consumers Marketing, 22(3), 142-151.

Memon, Y. J., Azhar, S. M., Haque, R., \& Bhutto, N. A. (2019). Religiosity as a moderator between theory of planned behavior and halal purchase intention. Journal of Islamic Marketing, 11(6), 1821-1836.

Montlvo, C. (2006). What Triggers Change and Innovation. Technovation, 26(3), 312-323.

Nazahah, A. R., \& Sutina, J. (2012). The Halal Product Acceptance Model for The Religious Society. Business Management Quarterly Review, 3(1), 17-25.

Ngah, A. H., Zainuddin, Y., \& Thurasamy, R. (2014). Contributing Factors of Halal Warehouse Adoption. Management and Technology in Knowledge, Service, Tourism and Hospitality, 89-94

Noar, S. M., Zimmerman, R. S. (2005). Health Behavior Theory and Cumulative Knowledhe Regarding Health Behavior: Are We Moving in the Right Directions? Health Education Research, 20(3), 275-290.

Omar, K. M., Mat, N. K. N., Imhemed, G. A., \& Ali, F. M. A. (2012). The Direct Effect of Halal Product Actual Purchase Antecedents Among the International Muslim Consumers. American Journal of Economics, 2, 87-92.

Pavlou, P. A., \& Chai, L. (2002). What Drives Electronic Commerce Across Cultures? Across Cultural Empirical Investigation of the Theory of Planned Behavior. J. Electron, Commerce Res., 3(4), 240-253.

Penang Monthly. (2019). Halal: More than Food- and Much more Holistic. [e-Newsletter]. Retrieve from https://penangmonthly.com/article.aspx?pageid=16959\&name=halal_more_than_foo d_and_much_more_holistic

Pettinger, C., Holdsworth, M., \& Gerber, M. (2004). Psychological Influence on Food Choice in Southern France and Central England. Appetite, 42(3), 307-316. 
Rahman, A. A., Asrarhaghighi, E., Rahman, S. A. (2015). Consumers and Halal Cosmetic Products: Knowledge, Religiosity, Attitude, and Intention. Journal of Islamic Marketing, 6, 148-163.

Rizwan, M., Raza, M. A., Mateen, M. A., Tehseen, F., Farooq, M. S., Javed, A., \& Javed, S. (2014). Investigating the Causes of Job Stress: A Study on Banking Sector of Bahawalpur, Pakistan. International Journal of Learning and Development, 4(2), 227.

Alam, S., \& Nazura, M. S. (2011). Applying the Theory of Planned Behavior (TPB) in Halal Food Purchasing. International Journal of Commerce and Management, 21(1), 8-20.

Shah, H., Aziz, A., Jaffari, A. R., Waris, S., Ejaz, W., Fatima, M., \& Sherazi, K. (2012). The Impact of Brands on Consumer Purchase Intentions. Asian Journal of Business Management 4(2), 105-110

Smith, A. D., \& Rupp, W. (2003), Strategic Online Customer Decision Making: Leveraging the Transformational Power of the Internet. Online Information Review, 27(6), 418-432.

Soon, J. M., \& Wallace, C. (2017). Application of Theory of Planned Behaviour in Purchasing Intention and Consumption of Halal Food. Nutrition and Food Science 47(5), 635-647.

Stone, M. (1974) Cross Validity Choice and Assessment of Statistical Prediction (with Discussion). Journal of the Royal Statistical Society, 36, 111-147.

Suki, N. M., \& Sulaiman, A. (2016). Does Halal Image Strengthen Consumer Intention to Patronize Halal Stores? Journal of Islamic Marketing, 7(1), 120-132.

Taylor, S., \& Todd, P. (1995). Understanding Information Technology Usage: A Test of Competing Models. Information Systems Research, 6(2), 144-176.

Trusov, M., Bucklin, R. E., \& Pauwels, K. (2009). Effects of Word-of-Mouth Versus Traditional Marketing: Findings from an Internet Social Networking site. Journal of marketing, 73(5), 90-102.

Tuten, T. L. \& Solomon, M. R. (2017). Social media marketing [eBook] Sage.

Warokka, A., \& Gallato, C. (2012). Do Customer Dissatisfaction and Variety Seeking Really Affect the Product Brand Switching? A Lesson from the Biggest Southeast Asia Mobile Telecommunication Market, Journal of Marketing Research \& Case Studies, 2012, 1.

Weaver, G. R., \& Agle, B. R. (2002). Religiosity and Ethical Behavior in Organization: A Symbolic Interactions Perspective. The Academy of Management Review, 27(1), 77-97.

Wilson, J. A. J., \& Grant, J. (2013). Islamic Marketing: A Challenger to the Classical Marketing Canon? Journal of Islamic Marketing, 4(1), 7-21.

Yoh, E., Damhorst, M. L., Sapp, S., and Laczniak, R. N. (2003). Consumer Adoption of the Internet: The Case of Apparel Shopping. Psychology and Marketing, 20(12), 1095-1118.

Yu, Y., and Wang, X. (2018). Purchase Intention Under Digital Peer Pressure-From the Perspective of Chinese Parents. The 24th Cross Strait Conference of Information Management Development and Strategy (CSIM 2018).

Yzer, M. (2007) Does Perceived Control Moderate Attitudinal and Normative Effects on Intention? A Review of Conceptual and Methodological Issues. In I. Ajzen, D. Albarracín, \& R. Hornik (Eds.), Prediction and Change of Health Behavior: Applying the Reasoned Action Approach. Lawrence Erlbaum Associates Publishers, 111-127.

Zhendehdel, M., Palm, L., Osman, S., \& Wright, L. T. (2015) Student's Online Purchase Behavior in Malaysia: Understanding Online Shopping Attitude. Cogent Business \& Management, 2(1)

Zhou, L. L. D., \& Zhang, D. (2007) Online Shopping Acceptance Model- A Critical Survey of Consumer Factors in Online Shopping. Journal of Electronic Commerce Research, 8(1), 41-62. 